\title{
AS CIDADES FRONTEIRIÇAS NA AMÉRICA DO SUL: POLÊMICAS E CONFLITOS COM O
} CETRO OESTE BRASILEIRO

\author{
The Border Cities in South America: Polemics and conflicts with the Brazilian Midwest
}

\author{
RITA DE CÁSSIA MARTINS SOUZA \\ Doutora em Geografia; Prof ${ }^{a}$ do Instituto de Geografia da UFU \\ ritacmsou@ig.ufu.br \\ ANA RITA FIDELIS DE OLIVEIRA \\ Graduanda em Geografia; Instituto de Geografia da UFU \\ arfidelis@yahoo.com.br
}

Artigo recebido em 31/08/2013 e aceito para publicação em 17/11/2013

DOI: 10.12597/tamoios.2014.7269

RESUMO As áreas transfronteiriças possuem um papel singular perante as intensas transformações produtivas advindas do chamado movimento globalizantes. A questão das fronteiras é tema de grande interesse em função da complexidade das relações envolvidas entre os Estados Nacionais, seja pelas interações entre cidades fronteiriças, pela mobilidade entre as populações, pelas relações de conflito ou cooperação. Perante tais transformações o trabalho enfoca as mudanças em que sofreu a definição e o papel das fronteiras, e os limites, linhas imaginárias reconhecidas internacionalmente pelos países a fim de proteger o Estado e sua soberania. Os limites entre o Brasil e seus vizinhos (a Bolívia e o Paraguai, mais particularmente) permitenos entender os relacionamentos entre esses países e as problemáticas que as circundam. Na sequência é feita uma breve análise do papel da interação, integração e os processos de mobilidade e fluidez na faixa de fronteira brasileira, analisando a influência da globalização e a unicidade do desenvolvimento econômico entre os Estados, em contrapartida o contato entre as comunidades na zona de fronteira.

Palavras-chave: Limites, Fronteiras, Zona de fronteira, integração e conflitos.

ABSTRACT The cross-border areas have a unique role in the productive transformations stemming from intense called globalizing movement. The issue of borders is topic of great interest due to the complexity of the relationships involved between the national States, either by the interactions between border cities for mobility between populations, relations of conflict or cooperation. Faced with such transformations work focuses on the changes in that suffered the definition and role of borders and boundaries, imaginary lines internationally recognised by countries in order to protect the State and its sovereignty. The boundaries between Brazil and its neighbors (Bolivia and Paraguay, more particularly) allows us to understand the relationships between these countries and the problems that surround. Following is a brief analysis of the role of the interaction, integration and the processes of mobility and fluidity in the Brazilian border, analyzing the influence of globalization and the uniqueness of economic development among the Member States, on the other hand the contact between communities in the border zone.

KeyWords: Boundaries, borders, border Zone integration and conflict. 


\section{INTRODUÇÃO}

Os movimentos de integração na América Latina vêm ganhando uma grande força nas últimas décadas por conta das intensas transformações produtivas advinda do chamado movimento globalizante. Essa tendência reforça a necessidade das pesquisas nas áreas de fronteiras entre os Estados envolvidos no sentido de compreender as dinâmicas novas e as antigas engendradas nos pactos estabelecidos entre as sociedades latinoamericanas.

O histórico das relações entre esses Estados sempre apontou um distanciamento relativamente grande entre essas sociedades, seja do ponto de vista de suas economias, seja do ponto de vista cultural. O Brasil, enquanto única colônia portuguesa da América manteve-se à margem dos antigos processos de unificação intentados desde o bolivarismo, no entanto, sempre manteve sua posição de país chave com uma inserção bastante significativa no mercado internacional, "obrigando" uma relação de permanente atenção por parte dos demais países da América.

Se isso é fato por um lado, por outro, deve-se ter em mente as inúmeras intervenções principalmente de caráter estatal no sentido de dinamizar as economias locais na busca pela superação do subdesenvolvimento implementada pela CEPAL - Comissão Econômica para a América Latina, por exemplo.

A imensa região central do continente sul americano, como não poderia deixar de ser, constituiu-se numa zona de conflitos que demandou a atenção dos governantes. Se recorrermos à história, poderemos verificar que o estabelecimento dos limites territoriais entre esses Estados, fundados durante o Século XIX, demandou esforços diplomáticos intensos no sentido de acertar os conflitos e outros esforços por parte dos Estados envolvidos no sentido de ocupação econômica das zonas fronteiriças, ações que ainda hoje têm desdobramentos.

Nesse sentido, vale resgatar os esforços dos diplomatas do período imperial, além do desenvolvimento técnico da cartografia usada no estabelecimento das divisas no Tratado de Madrid (1750). Acordado entre Espanha e Portugal, este Tratado marcou o uso de uma nova concepção na demarcação das fronteiras tendo como princípio o uti possidetis. Assim foram feitos os acordos com o Peru em 1851, com o Uruguai em 1851-2, com a Venezuela em 1859, com a Bolívia em 1867, e com o Paraguai em 1872.

Deve-se ainda lembrar a questão do Acre, cuja ocupação em função da exploração do látex por brasileiros quase explodiu em guerra no final do século XIX. A intervenção do ministro das Relações Exteriores, Barão do Rio Branco, é por demais conhecida.

\footnotetext{
Essa região inexplorada da América do Sul provocara reivindicações e contra reivindicações em todo o correr do século XIX, Vendo-se a braços com uma guerra no Paraguai, o Brasil desejava, em 1864, apaziguar os bolivianos pouco simpáticos à causa da Tríplice Aliança e, de fato, neutralizá-los no conflito... Com a área relativamente em paz, o chanceler [Rio Branco] começou a negociar. Os erros geográficos e tom vago do Tratado de 1867, assim como o fato de ser o Acre habitado por aproximadamente 60 mil brasileiros e quase nenhum boliviano, deram vigor e substância às pretensões do Brasil. Em virtude do boom da borracha, que aumentou a atividade no Amazonas nas derradeiras décadas do Século XIX, os seringueiros brasileiros, seguindo a tradição dos bandeirantes de São Paulo, do século XIX, tinham se espalhado pelo interior inexplorado, à procura do lucrativo leite branco da hévea. Os novos exploradores estabeleceram-se rapidamente na área do Acre e, pela sua presença, concretizaram os direitos do Brasil à propriedade da região pelo uti possidetis. (BURNS, 1985).
}

A questão das fronteiras, embora estejamos vivendo um contexto muito distinto daquele momento histórico passado, é ainda tema de grande interesse em função da complexidade das relações envolvidas entre os 
Estados Nacionais, seja pelas interações entre cidades fronteiriças, pela mobilidade entre as populações, pelas relações de conflito ou cooperação. Antes de tudo, deve-se atentar ao significado dos conceitos de fronteira e de limite empregados na geografia política.

Segundo Machado (1992), para se compreender melhor as áreas de contato entre os Estados do ponto de vista do povoamento, colonização e interação, as fronteiras no sentido de zonas ou regiões apresentam uma melhor adequação do que aquela utilizada no sentido imperialista ou militar. Embora envolvam a linha-limite, as zonas fronteiriças estendem-se para além delas, numa convergência de interesses, seja do ponto de vista, da integração ou do conflito. "No sentido mais geral, a noção de fronteira internacional como lugar de integração, de comunicação, de encontro, de conflito, advém da premissa de que estamos na presença de sistemas territoriais diferentes e de nacionalidades distintas". (MACHADO, 1992, p.256)

Tradicionalmente, incorporada à fundação dos Estados Nacionais modernos, a necessidade de demarcação entre unidades territoriais soberanas por linhas inconfundíveis apresenta extrema importância para se saber onde termina a soberania de um e onde começa a do outro: dentro dessa área delimitada se desenvolve a organização interna do Estado. Tradicionalmente também, estabeleceu-se o conceito de fronteira como área de defesa ou região defensiva, muito ligada à criação dos Estados. Essa concepção sofre hoje ressignificadas em função dos novos contextos estabelecidos. Do ponto de vista econômico configura-se uma situação de desperdício em função da duplicidade de infraestruturas como as redes viárias, usinas de energia, etc. Ainda segundo Machado, “... não é por acaso que um dos principais fatores a intervir na promoção da cooperação é a existência de uma elite política local empreendedora que esteja disposta a investir tempo, esforços e dinheiro em promover o desenvolvimento de redes transfronteiriças”. (Machado, 1992, p.259).

Interessante ainda a destacar da proposição de Machado (1992) é o conceito de "meio geográfico da fronteira”, ou seja, uma área com especificidades tais que exige um aporte diferenciado para a sua análise e compreensão, já que, sendo zona de interação internacional, envolve também interesses de ordem local e regional.

A região fronteiriça entre Brasil, Paraguai e Bolívia apresenta no contexto do grande projeto de pesquisa "Geografia Política: Polêmicas Contemporâneas”, relevância significativa. A área encontra-se hoje densamente povoada e com interações econômicas, políticas, culturais e militares importantes. Poderiam ser citados como pontos de interesse para esta pesquisa em particular, a criação do gasoduto Brasil-Bolívia, e as atividades agrícolas de brasileiros em território paraguaio. Ainda poder-se-ia mencionar a imensa região do Pantanal ou do Chaco que se constitui num elo importantíssimo do ponto de vista ambiental, mas também do ponto de vista da circulação: o projeto da grande hidrovia do Paraguai e suas funções para o MERCOSUL devem aqui ser lembrados.

Se considerarmos a importância do fluxo de capitais nessa área, podemos perceber questões de cunho bastante complexo a serem analisadas como, por exemplo, as normas constitucionais dos dois lados das fronteiras impondo limites à expansão do capital. No caso da legalidade das propriedades de estrangeiros (paraguaios ou bolivianos), a Constituição brasileira, de 1988, é bastante clara acerca da sua inviabilidade. No entanto, os investimentos brasileiros do lado paraguaio, por exemplo, são sabidamente bastante significativos.

No contexto brasileiro, o plano de marcha para o Oeste foi criado no governo Getúlio Vargas para a ocupação do Centro-Oeste com o interesse de promover a ocupação dos vazios demográficos. No contexto mundial, da Segunda Guerra, os países desenvolvidos procuravam ocupar espaços em países menos 
desenvolvidos, com isso, a região Centro-Oeste do Brasil se tornava um alvo em potencial de cobiça para autoridades internacionais, paralelamente, despertava o interesse de garimpeiros, fazendeiros e políticos.

O presidente Getúlio Vargas convidado a sobrevoar a região do Araguaia avistou aquele imenso "branco" do Brasil Central, assim delegou ao ministro da Coordenação de Mobilização Econômica, João Alberto Lins de Barros, a missão de interiorização do Brasil. Nasce então a Fundação Brasil Central, FBC. Em seguida, cria-se a Expedição Roncador-Xingu, cuja função era mapear o centro do país e abrir caminhos que ligassem a região ao resto do país, principiando o avanço progressista. Os estados periféricos como Goiás, Mato Grosso e Paraná, foram encarregados da produção de alimentos e de matérias-primas para abastecimento do Sudeste.

Essas políticas territoriais têm desdobramentos para a contemporaneidade. O gasoduto Bolívia-Brasil, por exemplo, tem seu inicio na cidade boliviana de Santa Cruz de la Sierra e seu fim na cidade gaúcha de Canoas, atravessando também os estados de Mato Grosso do Sul, São Paulo, Paraná, Santa Catarina, Rio Grande do Sul, passando por cerca de quatro mil propriedades em 135 municípios. Utilizando-se da energia hídrica da Bacia do Paraná, como ato de integração regional estabeleceu um sistema interligado de energia elétrica. Redes de transportes foram ampliadas devido ao relevo ser aplanado em sua maior extensão facilitando os fluxos terrestres de pessoas e mercadorias, e também grandes pontes fluviais construídas.

Geiger (2006) ainda nos relata sobre a interação entre Brasil-Paraguai. Antes da formalização do MERCOSUL houve forte migração de fazendeiros e trabalhadores rurais brasileiros para o Paraguai.

\footnotetext{
Dados do Fundo das Populações das Nações Unidas calculam em 600.000 , ou $12 \%$ da população total, o numero de estrangeiros vivendo no Paraguai, dos quais, 350.000 brasileiros, ou "brasiguaios". Por outro lado, conta-se, também em 12\%, os nascidos paraguaios que saíram de seu país, a maioria, como força de trabalho em São Paulo, outro contingente do movimento populacional é formado pó estudantes paraguaios, ou bolivianos frequentando universidades brasileiras. (GEIGER, 2006. P153).
}

Percebemos que agricultores e latifundiários brasileiros que cultivam principalmente a soja ocupam as melhores proporções de terra produtivas do Paraguai e em menor proporção da Bolívia. A insegurança desses países de que o Brasil futuramente reivindique estas terras como parte do seu território, leva os governos e as populações a se inquietarem com essas questões. Outro ponto agravante é a presença de indústrias brasileiras nesses países, sobretudo na Bolívia, além da posição de dependência energética do Paraguai para com o Brasil, devido aos acordos de produção de energia da usina de Itaipu.

Mediante toda esta problemática aqui esboçada, este trabalho tem como objetivo contribuir para a compreensão das disputas envolvendo Estados Nacionais contemporâneos na América Latina. Mais especificamente, traçar o histórico do estabelecimento das zonas fronteiriças entre Paraguai, Bolívia e Brasil; levantar os aspectos gerais que favoreceram a cooperação entre esses países e levantar os aspectos gerais que geram conflitos entre esses países.

Em meio à chamada globalização, os conflitos entre os estados sul americanos refletem uma tendência contrária ao próprio processo de integração global via empresas e, ao mesmo tempo, demonstra a iniciativa de alinhamento aos interesses mais amplos do capitalismo na forma de blocos econômicos.

Esta pesquisa constitui-se em mais um esforço de compreensão da realidade geográfica sul americana e justifica-se em função dos crescentes e permanentes problemas em relação ao desenvolvimento desses países. Pauta-se, basicamente, no levantamento bibliográfico geral acerca da globalização e dos conflitos regionais latino-americanos; no levantamento bibliográfico específico acerca da formação das fronteiras entre Paraguai, 
Bolívia e Brasil; no levantamento dos conflitos regionais presentes na área, através de jornais, revistas e sites de internet; e no levantamento de documentos pertinentes aos acordos de paz ou de cooperação entre os três Estados envolvidos.

Desta forma, o trabalho compõe-se de três partes principais. Na primeira, desenvolve-se uma revisão da bibliografia a cerca dos conceitos de limites e de fronteiras, procurando acertar uma conceituação mais adequada ao presente contexto histórico. Na segunda parte, procede-se a uma revisão detalhada do estabelecimento dos limites entre os Estados sul americanos como suporte para a compreensão da dinâmica dos conflitos e da integração contemporânea. A parte três dedica-se à questão das interações nas zonas fronteiriças entre Brasil, Bolívia e Paraguai para dar conta da "Geografia Política: Polêmicas Contemporâneas", focando-se maior atenção sobre o Centro Oeste brasileiro.

\section{FRONTEIRAS E LIMITES: INTERAÇÕES E CONFLITOS EM ZONA DE FRONTEIRA NA AMÉRICA DO SUL}

Fronteiras e limites são conceitos que demandaram bastante tempo para se estabelecerem cientificamente conforme o curso da história enquanto ordenamento político. Na verdade ainda continuam sendo pontos importantes a serem discutidos, para muitos pesquisadores, uma vez que inseridos no universo da globalização, com novos comportamentos e constantes mudanças na formação social. As discussões sobre o fim das fronteiras fazem com que os geógrafos retomem seu significado e como elas têm sido vivenciadas pelas próprias comunidades que ali se estabeleceram, como se dá a integração, os fluxos de pessoas e comércio, a legalidade e a ilegalidade dos mercados, enfim, a dimensão da interação entre essas comunidades que vivem tão próximas umas das outras e seus comportamentos diante da soberania do Estado, ao qual devem prestar contas.

A noção de fronteira vem sendo tratada desde bem antes do aparecimento do Estado Moderno, antes mesmo, portanto, da noção de limites internacionais. No Império Romano, a fronteira, ou limes, era uma questão de expansão dos seus domínios, áreas em que os militares se alojavam para guardarem determinada extensão, para atender aos interesses do imperador, sejam essas extensões pontos estratégicos para evitar aproximações de povos bárbaros, sejam para melhor circulação de suas mercadorias. Em terras monárquicas, os limites do reino estendiam-se até onde o poder do rei alcançasse, não havendo áreas estabelecidas rigidamente. Os domínios do rei terminavam onde os súditos de outro reino ali se encontrassem, portanto, eram territórios "instáveis" em constante movimento. Conforme nos recorda Rebeca Steiman (2002), na Europa medieval, séculos XIII e XIV, o termo fronteira era aplicado às zonas, e não simplesmente limites assim como nas extensões de um reino primitivo, mas áreas que possuíam extensões de forma a significar uma separação entre reinos e não áreas de contato. Essas áreas serviriam para impedir aproximações de povos bárbaros indesejáveis. Na verdade essas áreas se originaram nos séculos VII e VIII no período da Alta Idade Média, “... com a constituição dos 'marks', ou 'marches' (francês), ou 'marcas' (espanhol), pelos reis francos e germânicos, territórios especiais, usualmente objeto de projetos de colonização”. (STEIMAN, 2002. P. 4)

Dando um salto histórico para os séculos XV e XVI, a corrida imperialista entre os reinos da Europa, fez com que as fronteiras ultrapassassem a continuidade dos seus territórios, colonizando áreas recém "descobertas" pelos europeus dominando as terras e ali impondo suas leis. Com essa nova realidade as chamadas fronteiras naturais se tornaram imprescindíveis, pois para delimitar um determinado território pertencente a uma 
determinada monarquia contava-se com o auxilio da natureza, estabelecendo os limites da colônia através de separações naturais. A Cartografia foi aplicada especificamente para interesses do reino, e constituiu-se em estudos investidos pelas autoridades para conhecerem as terras exploradas a fim de dominar todo o território demarcando seus limites. Eram fixadas as separações entre os reinos concorrentes de acordo com os cursos hidrográficos, cordilheiras etc.

Com a emergência do Estado Moderno, a necessidade de legitimar os conceitos fronteira-limite foi de estrema importância, pois se começava a centralização de um poder político cuja soberania se impunha a um determinado território contendo um determinado povo. O sentido de um Estado só se dá com a existência de outro Estado. E cada Estado está ligado a um povo, uma organização política e um território conforme seu específico aparelho administrativo. A partir da formação do Estado-território, a oposição entre dois Estados devido a grupos políticos distintos naturalmente começou a gerar delimitações fixas desses territórios. A ideia de um fundamento racional para os limites naturais ainda ocorrem no século XX. Nas palavras de Steiman (2002)

O debate que surgiu entre franceses e alemães sobre a soberania francesa na Alsácia e no vale do Reno (que seria a 'fronteira natural' da França) deu margem ao aparecimento do conceito de fronteira baseado no princípio de que a base territorial do estado deveria ser linguística ou racial, posição defendida pelos humanistas alemães (...). No início do século XIX, uma nova doutrina de fronteira-limite vinculada à identidade nacional surgiu, não entre os franceses, mas entre os alemães. Usualmente se toma como marco o Discurso à Nação Alemã de J. Fichte (1807). A reação alemã à doutrina das fronteiras naturais dos franceses foi o conceito de fronteira baseado no princípio da nacionalidade. Fazendo uso de uma ideia mística de "povo", Fichte defende a unidade territorial do estado e de que seus limites sejam derivados da existência (histórica) de língua e cultura comuns. Diversos autores apontam que uma das principais consequências no século $\mathrm{XX}$ da doutrina de fronteira baseada na identidade nacional foi o conceito de autodeterminação dos povos. (Steiman, 2002. p.4, 5)

O que era tratado como Estado-território, desde o século XVIII, passa a ser compreendido como Território-Nação ou Estado-Nação, o qual pelo curso da história moderna foi forjado através de sentimentos de pertencimento pelas elites locais e suas ideologias fundamentadas em uma unidade entre o povo dando origem ao Estado Nacional Moderno, adequando-se às mudanças econômicas, culturais e políticas e enquadrando-se no complexo sistema capitalista. Esta concepção tem sua gênese na Revolução Francesa, o marco da unidade entre os povos e consolidação da burguesia no poder. É no contexto da formação dos Estados Nações que surge a noção de limites-internacionais.

Podemos observar por essa breve realização histórica, que a noção de fronteira emerge naturalmente conforme as transformações das sociedades, desde o medievo até a contemporaneidade: a fronteira acompanha a evolução de sociedades envolvidas em conquistas de territórios ou na proteção dos mesmos. Já o termo limite origina-se de uma conjuntura voltada especificamente aos assuntos jurídicos, à unidade política do território, como mencionado por Lia Osório Machado (1998).

A fronteira está orientada "para fora" (forças centrífugas), enquanto os limites estão orientados "para dentro" (forças centrípetas). Enquanto a fronteira é considerada uma fonte de perigo ou ameaça porque pode desenvolver interesses distintos aos do governo central, o limite jurídico do estado é criado e mantido pelo governo central, não tendo vida própria e nem mesmo existência material, é um polígono. O chamado "marco de fronteira" é na verdade um símbolo visível do limite. Visto desta forma, o limite não está ligado à presença de gente, sendo uma abstração, generalizada na lei nacional, sujeita às leis internacionais, mas distante, frequentemente, dos desejos e aspirações dos habitantes da fronteira. (MACHADO, 1998. P.42) 


\section{ZONAS FRONTEIRIÇAS: MOBILIDADES E FLUIDEZ}

Zonas fronteiriças são faixas de cada lado do limite internacional podem ser caracterizadas pelas interações internacionais que compõem formas de fluxo de bens, de capitais e de pessoas. Segundo Machado, essas interações, embora internacionais, criam um meio geográfico próprio de fronteira, perceptível em escala local/regional. Essas zonas de fronteiras caracterizadas apresentam "cidades gêmeas", formadas por comunidades que convivem e estabelecem suas próprias dinâmicas sejam por fronteiras secas ou fluviais, algumas contendo infraestrutura como pontes ou mesmo estradas, outras impedidas pela geomorfologia. (MACHADO, 2005.)

A importância dada aos estudos sobre as cidades gêmeas é para analisar a interação das zonas fronteiriças em relação ao restante do território nacional, pois algumas dessas cidades são esquecidas seu governo central, fato atestado pela má infraestrutura das estradas e pelas grandes distâncias ou até mesmo barreiras físicas que deveriam dar acesso às grandes cidades que teriam o mínimo suporte para $o$ desenvolvimento de sua economia local. O que se destaca é a interação entre a economia de cidades vizinhas estrangeiras as quais conseguem estabelecer uma dinâmica de troca tanto no aspecto econômico quanto no aspecto cultural.

Entre os diferentes tipos de fluxos, podemos destacar o fluxo de trabalhadores entre as faixas de fronteira. Uma cidade considerada mais desenvolvida do que a outra, por exemplo, tende a atrair trabalhadores da cidade menos desenvolvida onde lhe faltam recursos e empregabilidade. Trabalhadores do tipo diaristas ou sazonais saem em busca de empregos em empresas que não exijam qualificações. Machado (2005) cita um exemplo entre as cidades do Uruguai fronteiriças com as cidades do Rio Grande do Sul, em que se criou um acordo bilateral disponibilizando documentações que facilitam a circulação de pessoas e a permissão de trabalho. Outro caso são os fluxos de capitais, o Banco Central do Brasil, em determinadas regiões, legalizam a entrada e saída de capitais estrangeiros. Empresários ou cidadãos de um país estrangeiro preferem depositar seu dinheiro em bancos brasileiros, para proteger-se da instabilidade econômica de seu país de origem e também pelo fato de os bancos serem mais organizados e informatizados. Ainda, a procura de recursos naturais e terras mais baratas, instalações de unidades industriais e agroindustriais e menor rigor nas leis ambientais estimulam grandes migrações de pessoas a essas regiões como é observado pela autora nas cidades de Brasiléia (Acre) e Cobija (Bolívia). Os serviços de consumo coletivo também se tornam um atrativo de estrangeiros para as cidades brasileiras, onde os recursos são sustentados pelo governo, causando migrações de pessoas para serem atendidas nas unidades de saúde (SUS). A impossibilidade de atendimentos em suas próprias cidades por motivo da privatização de todos os sistemas de saúde local faz com que a população não tenha alcance aos serviços, assim recorrem ao auxilio do lado estrangeiro. Do mesmo modo, a assistência do corpo de bombeiros se desloca da cidade brasileira rumo à cidade do país vizinho, pois essas não contêm nenhuma corporação. (MACHADO, 2005)

Essas são apenas algumas das dinâmicas locais que ocorrem nas faixas fronteiriças, diante de tantas outras em que devem ser observadas em pesquisa de campo futura. As transformações a que estão sujeitos esses ambientes conforme as mudanças do sistema capitalista, em um mundo globalizado, alimentado pelo meio técnico-cientifico-informacional, levantam questionamentos sobre a ação do Estado diante de tais circunstâncias. Até que ponto o Estado tem interesse de interferir na interação do comércio e de transações de mercadorias? 
Como se daria a sobrevivência dessas comunidades se fosse aplicada com rigor à legislação e punidas as ilegalidades que muitas vezes movimentam a economia local? Como as constantes transformações do sistema mundo, serão tratadas nesses ambientes no âmbito das formações sociais, que atingem a cultura e a língua, como em alguns lugares que se encontra o bilinguismo e até mesmo pais que colocam seus filhos nas escolas do outro lado da fronteira recebendo influências de outra comunidade? Como devemos encarar as perspectivas sobre o fim das fronteiras proposto pela universalidade do capital, as interações de organizações e programas de livre comércio como o MERCOSUL? Qual a importância do Estado como mediador dessas novas relações? Observando essas comunidades e os acontecimentos não só nas faixas fronteiriças, mas no que se passa na integração com os seus respectivos países, acena-se a possibilidades de chegarmos a algumas respostas para essas questões.

Há necessidade de se retomar a teorização sobre as zonas de fronteira no contexto da globalização e da visão de um "mundo sem fronteiras", como coloca Rebeca Steiman (2002). Utilizando-se da tese de James Anderson, a autora aponta que as fronteiras econômicas, comunitárias e sociais estão deslocadas das fronteiras territoriais, pois o crescimento de fluxos de capitais transpassa essa noção de fronteira nacional, devido à evolução do sistema capitalista, como que uma contradição entre o binômio separação/interação, no qual a acumulação capitalista tende a destruir alguns obstáculos que são inoportunos à livre circulação de bens de capital, mercadorias, etc., ao mesmo tempo em que gera obstáculos de livre circulação conforme sua própria seletividade, apoiando-se na forma política do sistema de estados nacionais. (STEIMAN, 2002)

O “mundo sem fronteiras” refere-se, então, à universalização do capitalismo conforme desenvolvido por Arroyo (2005), no sentido de que o sistema capitalista apresenta "porosidade" conforme maior número de territórios possíveis, sendo controlado principalmente pela hegemonia mundial, embora a União Europeia já tenha organizado uma forma de unificar o seu mercado em um contexto de integração política e econômica, abrindo novas possibilidades para as regiões fronteiriças e mantendo a cooperação transnacional.

Como coloca RIBEIRO (2002), hoje se mantêm uma valorização da cooperação transfronteiriça dentro da transnacionalização da economia. A concepção de fronteira como uma área ou zona de comunicação, troca e transações é notavelmente o mais apropriado para os dias atuais. Para a maior fluidez do comercio internacional, a isonomia dos territórios nacionais é afetada de acordo com os interesses dos blocos supranacionais como MERCOSUL, NAFTA e a União Europeia. Regulamentos aduaneiros favorecem a circulação comercial em locais de fronteiras, diminuindo ou até mesmo suprimindo as tarifas alfandegárias no interior de cada bloco. Esses locais de limite passam a ter novos instrumentos jurídicos de acordo com as características de seu posicionamento, permitindo vantagens como, por exemplo, territórios especiais no interior dos EstadosNacionais conhecidos como Zonas Francas, Zonas de Livre Comércio, Zonas de Processamento de Exportações. Nesses espaços lhes é garantido um regime jurídico de exceção, que suspende ou altera normas que prevalecem no restante do país, fazendo com que a organização territorial também sofra alterações. Diferenciando as normas dentro de um mesmo território, originam-se novas organizações territoriais, como os "limites funcionais", que é comum se localizarem ao longo da zona contígua às divisas internacionais, que por sua vez, obedecem a padrões de centros atacadistas coincidentes com as cidades-gêmeas. (RIBEIRO, 2002)

Assim, os "Limites funcionais" criados para permitir o exercício das atividades da transnacionalização econômica, tornam-se 'mediações jurídicas' (SANTOS, 1996) que estabelecem as condições de operação das empresas que se localizam em certos lugares, materializando um conjunto de interações que passam a compor a estrutura da realidade, 
impondo-lhe novas ordenações territoriais. (RIBEIRO, 2002 P.6)

No que diz respeito à fluidez em zonas transfronteiriças, há nas margens dos Estados pontos de controle sobre os fluxos internacionais de bens e pessoas. Aeroportos, EADIs (Estações Aduaneiras Interiores) e portos secos. Este último, comum no Brasil, é definido como um terminal alfandegário que presta serviços públicos de movimentação e armazenamento de mercadorias sob controle aduaneiro através de empresas terceirizadas, empresas conhecidas como maquiladoras. Essa função de controle privilegia a fluidez do comércio internacional, que se dá em centros regionais situados em entroncamentos de vias de circulação, com proximidade também dos principais centros produtores e consumidores do país. (RIBEIRO, 2002.)

Embora haja função de controle em áreas de limites, atentamos para a existência de certas regiões de fronteira que são "lugares não-controlados" (Albuquerque, 2008), com maior densidade populacional, por onde circulam terroristas, drogas, armas, e imigrações ilegais, que estão fora do controle central. As cidades-gêmeas possuem uma função de centralidade em termos de fluxos econômicos, como se configura espacialmente nos casos da zona de fronteira brasileira-platina. A estrutura dessas cidades é complementar entre elas, devido ao seu padrão diversificado de produção, de serviços, de bens, de pessoas, de informações e a variação dos preços de produtos agrícolas, sejam fatores legais ou ilegais. Esses componentes de fluxos são facilmente observados em cidades gêmeas que se situam em fronteiras "secas" ou com aquelas que possuem infraestrutura como pontes ou serviços de transporte apropriado. Há uma dinâmica de interações espaciais em cidades gêmeas, consequência da diferenciação das estruturas produtivas e entre as economias nacionais. (RIBEIRO, 2002)

\section{FRONTEIRAS EM MOVIMENTO E INTEGRAÇÃO EM ZONAS DE FRONTEIRA}

O conceito de fronteira em movimento compreende a dinâmica das imigrações fronteiriças em uma determinada faixa de terras entre dois Estados. A princípio, como já vimos discutindo, entendia-se fronteira como frente de expansão, lugar de afirmação das identidades nacionais, como no caso das ações dos bandeirantes e dos pioneiros, com a ideia de conquista e de expansão de acordo com os primeiros tratados do período colonial, no Brasil. As fronteiras estatais eram tratadas como "organismos vivos" mediante processos de expansão e retração. Hoje, vêm sendo tratadas como áreas de identidades híbridas e ambíguas (hibridismo cultural), pois se configuram em um espaço de misturas e fluxos culturais. Nas palavras de Albuquerque "as fronteiras em movimento são espaços sociais de tensões, contradições e junções. As zonas de fronteiras são campos de força e choques políticos e simbólicos, mas também de variadas misturas culturais e formas de integração". (ALBUQUERQUE, 2008. P.56)

O "hibridismo" cultural e linguístico deve-se a imigrações populacionais nas zonas de fronteiras entre países vizinhos, como por exemplo, a imigração de brasileiros no Paraguai principiada nos anos de 1950 e intensificada nas décadas de 1960 e 1970, principalmente pela proposta da construção da Hidrelétrica de Itaipu. Segundo as informações de Albuquerque, os imigrantes brasileiros se concentraram nos departamentos paraguaios que são limítrofes com o Brasil, o Alto Paraná, Canindeyú e Amambay e outros departamentos de Caaguazu, Itaipu e Caazapa. Foi nessas regiões que se formaram colônias e cidades em que predominam a língua portuguesa, canais de televisão, músicas e tradições culturais do Brasil. Com esse fenômeno, o processo migratório ocasionou o alargamento da faixa de fronteira entre os dois países, em que, segundo o autor, o contato e dinâmica espacial vão além das imediações dos limites políticos, como nas cidades de Salto de Guairá - Guaíra 
$\overline{\text { Mundo Novo, Cidade do Leste - Foz do Iguaçu e Pedro Juan Caballero - Ponta Porã, mas chegam a municípios }}$ situados a até 100 quilômetros ou mais do limite internacional, como Santa Rita, Naranhal, Santa Rosa, San Alberto, Mbaracayu etc. Nessa fronteira não há apenas a mistura cultural, mas devido ao desenvolvimento econômico desigual há também disputas políticas e econômicas entre os dois países. (ALBUQUERQUE, 2008)

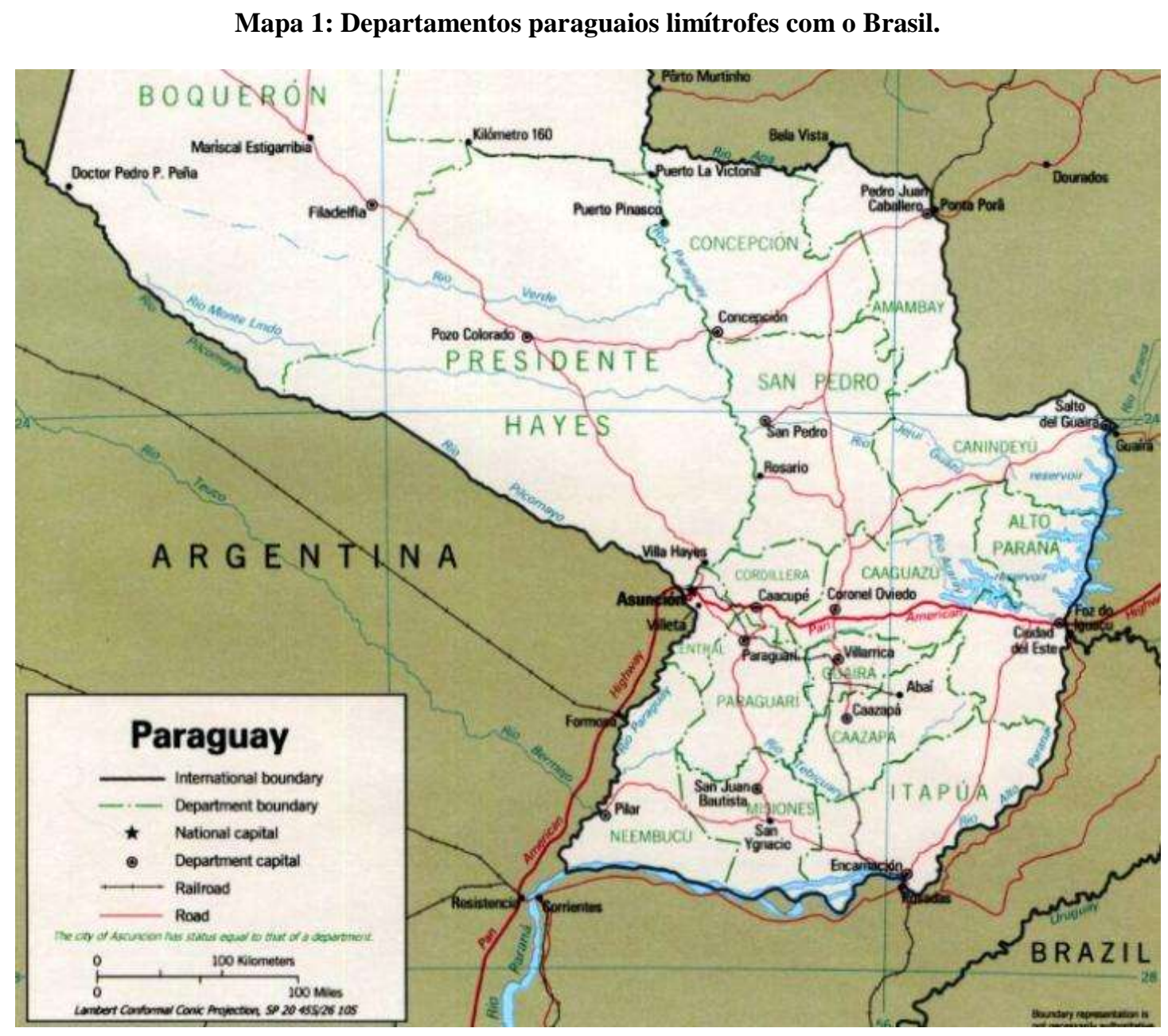

Fonte: http://www.portalsaofrancisco.com.br/alfa/paraguai/mapa-do-paraguai.php

O lugar se torna paulatinamente um ambiente de mescla cultural e de identidade. No caso específico do Brasil-Paraguai, os limites políticos são suplantados pelos limites culturais. A fronteira projeta-se como um espaço de trocas e integração social, uma zona de contato. É um espaço também de ambiguidade por existirem conflitos gerados pelas diferenças culturais, mas também por possuírem uma conexão cultural, como por exemplo, o espaço "brasiguaio". Brasileiros e descendentes que vivem nos departamentos acima citados como os de Amambay e Canindeyú, continuam se comunicando em português em seu próprio ambiente e seus filhos são matriculados nas escolas locais o que torna obrigatório aprender o espanhol, e, em convívio com os paraguaios, familiarizam-se com algumas palavras em Guarani. Para esse contato o autor utiliza-se do termo portuguarañol. (ALBUQUERQUE, 2008)

Em nível estatal a zona de fronteira é um problema, visto os conflitos que se desenrolam há décadas, consequentes da disputa por terras entre os imigrantes brasileiros proprietários de fazendas na região Leste do Paraguai e os camponeses paraguaios que promovem grandes tensões entre os governos e a própria população. 
São frequentes as crises não apenas causadas por posse de terras, mas também pelo choque entre as culturas camponesas e indígenas e o novo sistema produtivo trazido pelos imigrantes.

Quanto à integração social, além dos aspectos de imigração há também um trânsito fronteiriço entre os países do MERCOSUL. Trata-se do atendimento à saúde como anteriormente mencionado. Há uma demanda de estrangeiros que vêm se consultar nos sistemas únicos de saúde - SUS, principalmente em cidades gêmeas do lado brasileiro, uma vez que, pela constituição de 1988 é garantido o direito de assistência à saúde gratuita ao cidadão como uma responsabilidade do Estado. Esse trânsito é favorecido por pontes ou transportes como balsas que dão acesso aos municípios brasileiros onde se encontra um sistema de saúde com melhores condições que de seus próprios municípios de partida. Além de ser gratuito, também apresenta a vantagem da qualidade dos serviços (em alguns há inexistência dos serviços de saúde no seu país de origem ou precariedade dos serviços), e por último, as campanhas de vacina. Estas são informações levantadas através da pesquisa de campo feita por Nogueira e Dal Prá (2006). Segundo essa pesquisa o percentual de atendimento aos estrangeiros é de: Foz do Iguaçu $(28,2 \%)$, Guaíra (8,4\%), Santana do Livramento (7,4\%), São Borja e Uruguaiana (6,4\%), Santa Helena $(5,4 \%)$, Missal (4,9\%), Quarai e Bajé $(3,4 \%)$ e Jaguarão (2,9\%), nos demais municípios oscilam em torno de $0,99 \%$.

O cadastro de atendimento não é obrigatório em algumas áreas ao longo da fronteira, e em outros casos, os estrangeiros fornecem comprovantes de endereço das casas de amigos brasileiros residentes nos municípios das unidades de saúde como garantia, assim, podendo ser atendidos nos ambulatórios locais. Do mesmo modo, ocorre com os brasiguaios que não possuem documentação nem brasileira e nem paraguaia. Muitos nascidos no Paraguai, porém filhos de brasileiros, não possuem sequer uma certidão de nascimento, assim impossibilitando o acesso legal ao SUS. (NOGUEIRA; DAL PRÁ, 2006). No entanto, as cidades que possuem as condições melhores como os de serviços de saúde e até mesmo de educação ficam sobrecarregadas em vista dessa circulação de pessoas.

Apesar da heterogeneidade das zonas transfronteiriças, em que há níveis de desenvolvimento e características culturais distintas entre as cidades, os fluxos transfronteira fazem com que essas áreas tenham elementos comuns, como trabalho, terra, fluxos de capitais, serviço de consumo coletivo (saneamento, educação, saúde etc.), todos dependentes das características das cidades envolvidas e o seu segmento de fronteira. Cidades como Brasiléia e Cobija, situadas nos limites entre o Brasil e Bolívia, por exemplo, são cidades que apresentam fluxos de trabalhadores diaristas ou sazonais, como vem sendo relatado pela imprensa ilustrando o cotidiano dessas pessoas e todo o dinamismo do comércio entre elas. Esses trabalhadores são atraídos pela oportunidade de trabalhar com os seus próprios recursos e uma maneira de sustentar suas famílias com serviço formal ou informal. Este é o caso, por exemplo, de diaristas que, por exemplo, atuam como taxistas que moram em Brasiléia (Brasil), mas durante o dia prestam serviços em Cobija (Bolívia), sendo essa cidade mais populosa que a primeira. Essa facilidade deve-se a uma característica peculiar entre as cidades citadas, pois o limite fronteiriço entre elas é simplesmente uma avenida pavimentada com comércio e residências dos dois lados.

Ao longo dos 15.719 quilômetros de fronteira, a maior parte das cidades gêmeas se encontra no Arco Sul da fronteira continental desse país, compreendendo os estados de Mato Grosso do Sul, Paraná, Santa Catarina e Rio Grande do Sul que são limítrofes com Paraguai, Argentina e Uruguai. Os arcos e sub-regiões da faixa de fronteira serão melhor apresentados e discutidos mais adiante.

Logo abaixo uma representação dos arcos e sub-regiões da faixa de fronteira, numericamente dividido, 
distinguindo cada arco e sua área de abrangência.

Mapa 2: Arcos e sub-regiões da Faixa de Fronteira.

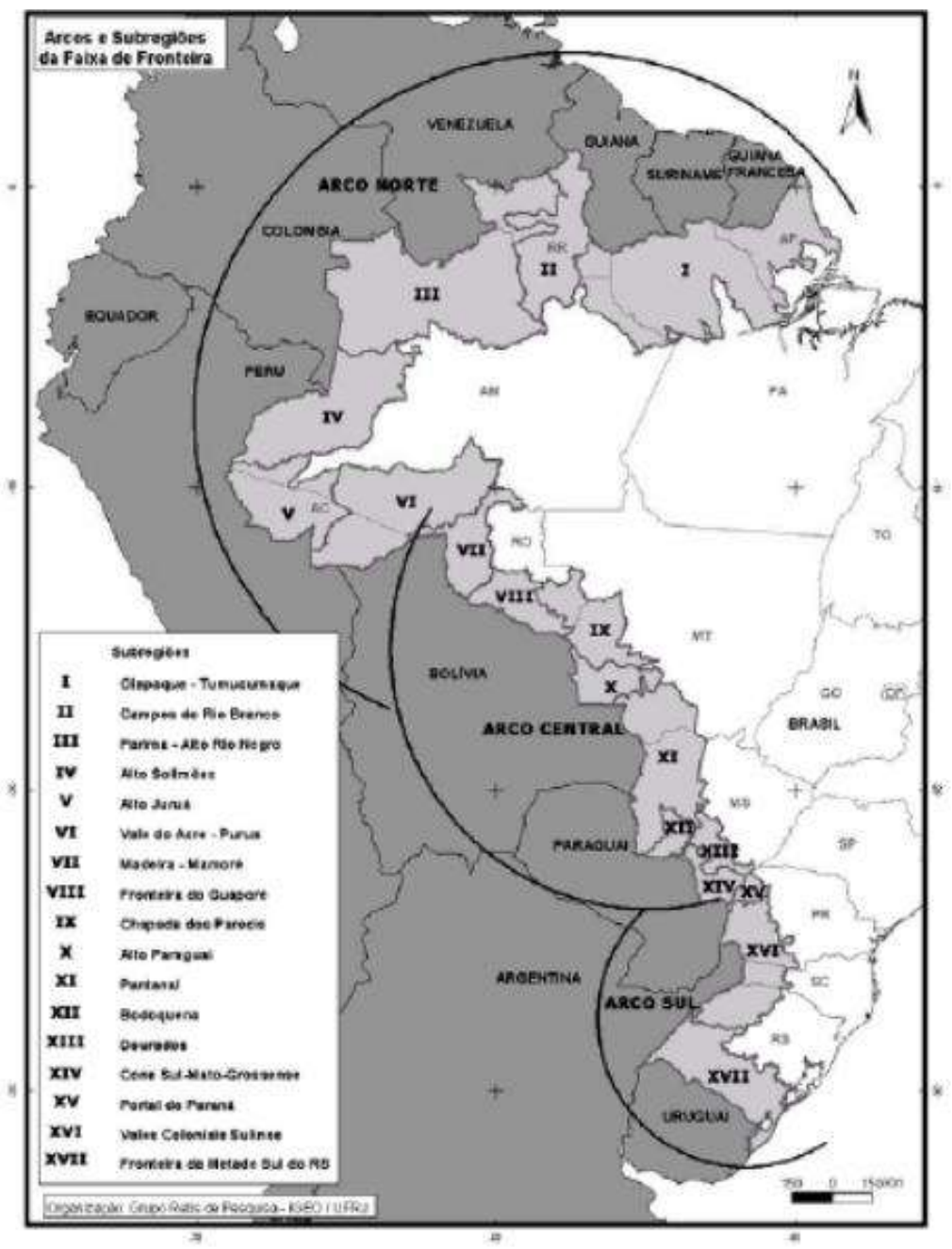

\begin{tabular}{|cl|}
\hline & Subregibes \\
II & Oiapoque - Tumucumaque \\
III & Pampos do Rio Branco \\
IV & Alto Solimóes \\
V & Alto Juruá \\
VI & Vale do Acre-Purus \\
VII & Madeira-Mamore \\
VIII & Fronteira do Guaporó \\
IX & Chapada dos Parecis \\
X & Alto Paraguai \\
XI & Pantanal \\
XII & Bodoquena \\
XII & Dourados \\
XIV & Cone Sul-Mato-Grossense \\
XV & Portal do Paraná \\
XVI & Vales Coloniais Sulinos \\
XVII & Fronteira da Metade Sul do RS \\
\hline
\end{tabular}

Fonte: PDFF, 2005. p. 53.

De acordo com o segmento de fronteira, Machado (2005) aplica modelos de interação às cidades gêmeas que são: as margens; zonas-tampão; frentes; capilar e sináptico. Para o Brasil são aplicados os três últimos modelos. O Modelo frente, comum apenas no Arco Norte do continente, se caracteriza por frentes pioneiras de povoamento, como a frente cultural e a frente militar, que sinaliza a presença do Estado, e a frente indígena, essa localizada somente no Acre fronteira com Santa Rosa (Peru). Já os modelos do tipo capilar apresentam trocas difusas espontâneas entre as cidades sem nenhum patrocínio do governo, como são os casos de Corumbá (MS) e Puerto Quijaro/Puerto Suárez (BO). O terceiro modelo é o sináptico que se caracteriza por trocas intensas de fluxos comerciais internacionais e interurbanos com grande apoio do Governo, com infraestrutura especializada e apoio ao intercâmbio. A tríplice fronteira formada por Ciudad Del Este no Paraguai Puerto Iguazú na Argentina e Foz do Iguaçu no Brasil representa esse modelo. (MACHADO, 2006)

Carla Mendonça faz duas tipologias desse último modelo que, segundo ela pode ser estrutural ou conjuntural. Na interação sináptico-conjuntural, como é o caso da fronteira do Paraguai com o estado brasileiro do Mato Grosso do Sul, aparecem interações caracterizadas pela frente agrícola de produção e pelo comércio 
ilícito. Já na interação sináptico-estrutural, aparecem relações urbanas e rurais, com propriedades rurais que se estendem de um lado a outro da fronteira, tendo um intenso intercâmbio cultural e de trabalho, como no caso da Campanha Gaúcha, nas divisas do Brasil com Uruguai e Argentina. (MACHADO, 2006, e MENDONÇA, 2009).

A integração fronteiriça no espaço geográfico do MERCOSUL traz consigo vários problemas vividos pelas comunidades fronteiriças. Alguns dos principais problemas estão ligados aos "corredores de passagem" de mercadorias: são frequentes os fechamentos de estabelecimentos e desempregos, por conta de ajustes cambiais e crises financeiras nacionais.

Ainda, outros problemas nas atividades transfronteiriças, segundo Mendonça (2009) são:

\begin{abstract}
Morosidade no atendimento aos turistas e abandono de estruturas de serviços turísticos; falta de coordenação das ações das polícias; restrições ao trânsito de mercadorias de varejo, não reconhecimento do comércio local e comércio irregular; decisões governamentais unilaterais; trânsito de trabalhadores com pouca qualificação profissional, sem carteira de trabalho, sem normas trabalhistas e previdenciárias; migrações e crescimento demográfico; ausência de sistema de identificação dos moradores da zona fronteiriça - a chamada "carteira de fronteiriço" -; presença de catadores e flanelinhas; falhas no transporte urbano; tráfego internacional de veículos a trabalho sem regulamentação; e falta de organização social. Tudo isso somado a ações ilícitas - tráficos, contrabandos -, à violência e a violações de direitos humanos. Ações de repressão dos governos dos Estados nacionais, como ao contrabando, acabam muitas vezes reduzindo a procura de serviços, como de bares e restaurantes, e causando outros resultados não desejados. (MENDONÇA, 2009, P21-22)
\end{abstract}

Essa é a configuração geral das zonas de fronteiras que, como se procurou demonstrar, são regiões vulneráveis a todos os tipos de situações concernentes ao contato entre sociedades distintas, mas que, em vista de necessidades de sobrevivência ou de comunicações com o "mundo externo", são submetidas à integração, o que, se torna uma questão a ser administrada permanentemente pelos Estados envolvidos.

No contexto da internacionalização da economia, a experiência de integração promovida na América Latina, tem feito com que áreas de fronteira despertem grande atenção. Mesmo em meio à globalização e à unicidade do desenvolvimento econômico entre os Estados, atualmente a fronteira tem se mostrado como um espaço de contradições e interações. Ao mesmo tempo em que essas regiões se estabelecem como um lugar de desenvolvimento, que apresenta avanços sociais, políticos e culturais, por outro lado, o Estado tem dificuldades de resolução, em questões como tráfico, contrabando, comércio ilícito etc. Com a modernização da tecnologia, da informação e da circulação, os espaços fronteiriços ganharam suporte para uma melhor comunicação entre si, como pontes, estradas, embarcações, navegação enfim, tudo aquilo que promove um fluxo entre as cidades. $\mathrm{O}$ mundo "sem fronteiras" da era globalizada precisa ser melhor questionada mediante as evidências de que a lógica moderna é bem adequada ao "mundo" do mercado e do capital, atendendo ao interesse de transnacionais, de multinacionais.

A fronteira é um lugar que sofre constantes mudanças, pois nela há comunidades que influenciam a transformação espacial conforme suas necessidades. Quanto mais se produz, mais o espaço é modificado, e quanto mais o espaço se modifica, maior é a necessidade de produção. Essas alterações valem tanto para as comunidades que moram ali, quanto para as multinacionais que se estabelecem nessas regiões ou próximas a elas. Este trabalho procura mostrar essas alterações na dinâmica do funcionamento das Zonas Francas, Zonas de Livre Comércio, Zonas de Processamento de Exportações, EADIs (Estações Aduaneiras Interiores). Estas funcionam como agentes que modificam o espaço a fim de aperfeiçoar a sua produção e consumo e, otimizar o seu tempo. 
A partir de toda a conceituação sobre fronteira e limites aqui desenvolvida, entende-se como fundamental retomar o estabelecimento dos limites entre os Estados sul americanos, antes de proceder-se à discussão e compreensão das zonas transfronteiriças de integração e de conflitos no subcontinente.

\section{A FRONTEIRA DO BRASIL COM A BOLÍVIA E O PARAGUAI: O "ESTATUTO DA FRONTEIRA"}

A proposta de reestruturação do programa de desenvolvimento da faixa de fronteira (PDFF) é um trabalho elaborado pelo Governo Federal junto ao Ministério de Integração Nacional, com o objetivo de "definir uma agenda global de diretrizes, estratégias e documentos de ação a fim de conduzir o desenvolvimento econômico regional e promoção da cidadania dos povos da fronteira” (PDFF, 2005). Este projeto está organizado em quatro etapas de pesquisa, visando conhecer a complexidade da região fronteiriça. Contempla o levantamento de dados procurando responder as seguintes questões: como a população se relaciona com a riqueza econômica, a produtividade, as identidades culturais e regionais, a interação com os seus países vizinhos dentre outras informações até chegar a um resultado necessário para a criação do Estatuto da Fronteira.

Conforme a Constituição brasileira de 1988, a faixa de fronteira do Brasil com seus países vizinhos foi estabelecida em $150 \mathrm{~km}$ de largura (Lei 6.634, de 2/5/1979), paralela à linha divisória terrestre do território nacional. Uma área recheada de complicações como a distância e a dificuldade de comunicação com os principais centros. Sendo um país voltado para as necessidades das áreas mais ao "Atlântico", o governo brasileiro promove estudos para que se possa compreender as políticas públicas necessárias à zona de fronteiras. Pauta-se no acordo com o programa de desenvolvimento realizado por professores do Departamento de Geografia integrantes do Grupo Retis da UFRJ e por uma Coordenação Institucional do Ministério da Integração Nacional. Além do Brasil apenas mais cinco países reconhecem a faixa ou zona de fronteira como uma unidade espacial distinta e sujeita à legislação especifica. (PDFF, 2005. P.9)

Assim como mostra o quadro elaborado por Rebeca Steiman (2002) sobre a faixa de fronteira na América do Sul, com destaque para a Bolívia e Paraguai:

\begin{tabular}{|l|l|l|}
\hline \multicolumn{1}{|c|}{ Países } & \multicolumn{1}{c|}{ Faixa de Fronteira } & \multicolumn{1}{c|}{ Instrumento Legal } \\
\hline Argentina & Não tem & Constituição de 1994 \\
\hline Bolívia & $\mathbf{5 0 ~} \mathbf{~ k m}$ & Constituição de 1967, reformada em 1994. \\
\hline Brasil & $\mathbf{1 5 0} \mathbf{~ k m}$ & Constituição de 1988 \\
\hline Chile & Não tem & Constituição de 1980, reformada em 2001. \\
\hline Colômbia & Não especifica a largura & Constituição de 1991, reformada em 1997. \\
\hline Equador & Não especifica a largura & Constituição de 1998 \\
\hline Guiana & Não tem & Constituição de 1980, reformada em 1996. \\
\hline Guiana Francesa & & \\
\hline Paraguai & Não tem & Constituição de 1992 \\
\hline Peru & 50 km & Constituição de 1993 \\
\hline Suriname & Não tem & Constituição de 1987, reformada em 1992. \\
\hline Uruguai & Não tem & Constituição de 1997 \\
\hline Venezuela & Não especifica a largura & Constituição de 1999 \\
\hline
\end{tabular}

Tabela: Faixa de Fronteira na América do Sul

Fonte: Brasil e América do Sul: Questões Institucionais de Fronteira. Rebeca Steiman (2002)

O projeto apresenta uma distinção entre faixa e zona de fronteira. Segundo o Programa, a faixa de fronteira "constitui uma expressão de jure, associada aos limites territoriais do poder do Estado", já o conceito de zona de fronteira "sugere um espaço de interação, uma paisagem específica, com o espaço social transitivo, 
composto por diferenças oriundas da presença do limite internacional, e por fluxos e interações transfronteiriças, cuja territorialização mais evoluída é a das "cidades-gêmeas"”. (PDFF, 2005. P.21)

A zona fronteiriça é uma área de interações culturais, políticas e econômicas e de conflitos, como visto no primeiro capítulo deste trabalho. A figura abaixo ilustra as interações transfronteiriças entre grupos locais e entre países na faixa de fronteiras:

Figura: Conceito Faixa e Zona de Fronteira

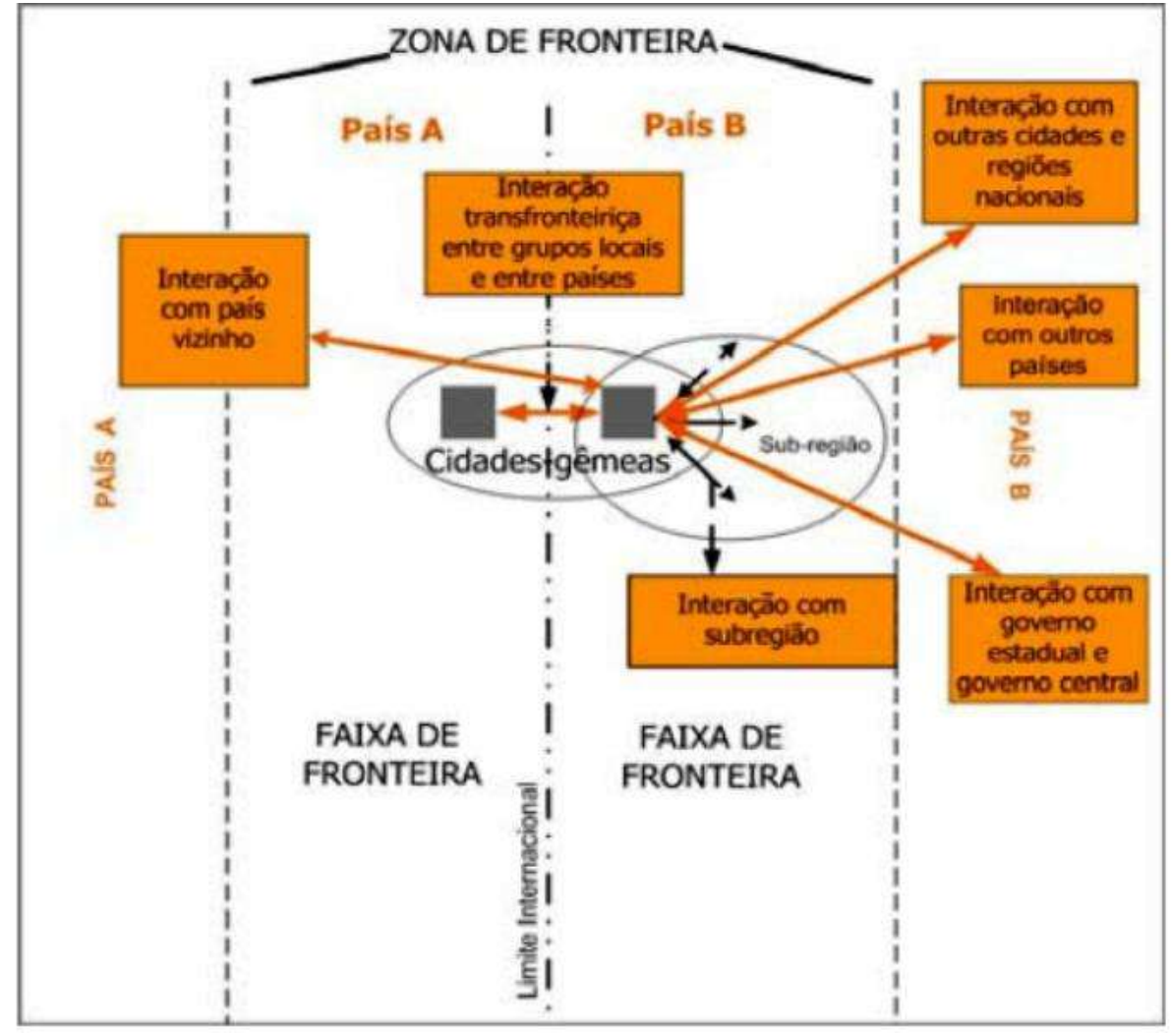

Fonte: Proposta de reestruturação do programa de desenvolvimento da faixa de fronteira, 2005.

No Brasil, a área de fronteira pode ser dividida em três macros segmentos, os Arcos Norte, Central e Sul, estes arcos são subdivididos em sub-regiões constituídas por agrupamentos de municípios, conforme ilustrado pelo Mapa 2 - Arcos e sub-regiões da Faixa de Fronteira. A identificação das sub-regiões foi definida pelos fatores: desenvolvimento regional e identidade cultural. Machado (2005) especifica esses fatores: no desenvolvimento regional se enquadra a "densidade econômica (base produtiva e especializações produtivas, mercado de trabalho, serviços à produção, conectividade); densidade técnico-tecnológica; densidade social; densidade institucional", quanto à identidade cultural, a autora coloca como fundamentais "elementos quantitativos (migração, etnia, praticas religiosas) e qualitativos (referências indenitárias, históricas, regiõespaisagem)". (MACHADO, 2005. P.6) 


\title{
AS MACRORREGIÕES
}

A primeira macrorregião é o Arco Norte composto por 71 municípios representando $12 \%$ do total de municípios da Faixa de Fronteira. Este foi subdividido em seis sub-regiões: A sub-região OiapoqueTumucumaque; a sub-região Campos do Rio Branco; a sub-região Parima-Alto Rio Negro; a sub-região Alto Solimões; a sub-região Alto Juruá e, por último, a sub-região Vale do Acre-Alto Purus. O segundo é o Arco Central composto por 99 municípios representando $17 \%$ do total de municípios da Faixa de Fronteira, este foi subdividido em oito sub-regiões: A sub-região Madeira-Mamoré; a sub-região Fronteira do Guaporé; a subregião Chapada dos Parecis; a sub-região Alto Paraguai; a sub-região Pantanal; a sub-região Bodoquena; a subregião Dourados e a sub-região do Cone Sul-mato-grossense. A terceira e última macrorregião da faixa fronteiriça no Brasil é o Arco Sul composto por 418 municípios representando 69\% do total de municípios da Faixa de Fronteira, subdividido em três sub-regiões: a sub-região Portal do Paraná; a sub-região Vales Coloniais Sulinos com os segmentos Sudoeste do Paraná, o segmento Oeste de Santa Catarina e o segmento Noroeste do Rio Grande do Sul; e por último a sub-região Fronteira da Metade Sul do Rio Grande do Sul. (PDFF, 2005)

Os dois países relacionados a este estudo, a Bolívia e o Paraguai, estão localizadas principalmente no Arco Central, uma área de encontro entre as duas maiores bacias hidrográficas sul-americanas, a Bacia Amazônica e a Bacia do Paraná-Paraguai. De acordo com as informações da proposta de desenvolvimento da faixa de fronteira, a sub-região Madeira-Mamoré é uma área que concentra 20\% da população do Arco Central “com 424.000 habitantes distribuídos numa área de $65.897 \mathrm{~km}^{2}$, sendo $80 \%$ urbana, a maior parte concentrada na capital de Rondônia e, secundariamente, em Guajará-Mirim, cidade-gêmea na fronteira com a Bolívia, no vale do Rio Mamoré”. No município de Nova Mamoré, a produção de gênero alimentício, além de consumo próprio, é exportada para o lado boliviano em pequena escala. "Tanto a capital como as pequenas cidades da região atuam como entrepostos de antigas redes comerciais com a Bolívia (Guayaramerín e Riberalta) e com a Subregião Vale do Acre e Alto Purus". Há também problemas como tráfico de drogas e mercadorias e relações institucionais identificadas nessa sub-região.

\begin{abstract}
A polarização exercida por Porto Velho ( $82 \%$ das indústrias de transformação) dificulta o crescimento de empreendimentos industriais no restante da Sub-região. Guajará-Mirim, situada em área antiga de povoamento vinculada à extração transfronteiriça da borracha nativa (inicio do século XX) tornou-se nas últimas décadas do século importante ponto de passagem para o tráfico de pasta base de coca e de cocaína procedente da Bolívia. O tráfico de drogas estimulou e reforçou correntes de contrabando na fronteira. A transformação da cidade-gêmea boliviana de Guayaramerín em porto franco incentivou o 'turismo de compra', até 1999 quando o governo brasileiro reduziu a quota de compras para USD 150,00, ao mesmo tempo em que crescia a exportação de produtos eletroeletrônicos de fabricação brasileira para a Bolívia, prejudicando o comércio de ambas as cidades. Como ocorre em outros segmentos da Faixa de Fronteira, empecilhos fiscais ao trânsito de mercadorias (lícitas) incentivam atividades de contrabando, sendo que no caso da Sub-região produtos extrativos (borracha, pupunha, madeira em tora), gado bovino e cigarro dominam o comércio de contrabando. Também à semelhança de outros segmentos da Faixa, a compra de terras por brasileiros do outro lado da fronteira e empreendimentos privados conjuntos atuam positivamente no estabelecimento de relações institucionais. O principal potencial da Subregião - a posição geográfica na bacia do Madeira-Mamoré - seria beneficiado pelo asfaltamento da estrada até Riberalta e sua extensão até Yata, Trinidad e Santa Cruz de la Sierra na Bolívia. (PDFF, 2005, p. 85)
\end{abstract}

Segundo pesquisas e dados levantados por Machado (2005), a macrorregião do Arco Central é composta por "frentes" agropecuárias, em meio a grandes e pequenos produtores rurais; pelo sistema produtivo 
"pantaneiro", com grandes fazendas de gado de corte; pelo agronegócio (soja, milho, cana de açúcar, algodão); pelo sistema industrial-comercial, e, por último, a indústria de confecção, encontrada em grandes, médios e pequenos centros urbanos constituindo uma das principais formas de geração de emprego e renda.

As relações fronteiriças entre Brasil e Bolívia dividem-se, conforme o programa, em capilar e frente de expansão pioneira. A primeira é relacionada à fronteira do Acre e de Rondônia, devido às atividades mercantis, como gênero alimentício, e também pelo tráfico de drogas ao longo da fronteira. Algumas cidades são articuladas por infraestrutura, outras não. Cobija e Brasiléia, caracterizadas como "cidades-gêmeas", são ligadas por uma ponte e podem chegar a uma relação sináptica pelo comércio. O segundo segmento de fronteira pode ser relacionado com a fronteira da Bolívia e o Estado do Mato Grosso, área onde há cultivo de soja, alimentos, exploração mineral e exploração madeireira. Dentro dos acordos bilaterais entre o Brasil e seus vizinhos, o segmento de fronteira mais significante é o sináptico, pois depende da intervenção do governo para a organização da infraestrutura social e de comunicação, devido ao constante intercambio com o outro lado da fronteira.

Com essa diversidade na faixa de fronteira é que houve a necessidade de se tratar de maneiras particulares cada segmento de fronteira nacional. No caso da Bolívia, há uma interação singular entre o país com o Brasil, como por exemplo, a relação bilateral no campo energético com a importação do gás boliviano que gera uma dinâmica especial entre os dois países. Outros acordos se dão no campo dos transportes vinculados à rodoviária e também às linhas férreas e na cooperação técnica. Já o Paraguai, é conhecido como o segundo maior parceiro comercial do Brasil na América Latina. A particularidade entre os dois países é a integração física, com a ponte do Rio Paraná e a construção da usina Itaipu, a hidrelétrica que gera, para todo o Brasil, 22\% de sua energia.

\section{RELAÇÕES TRANSFRONTEIRIÇAS}

O grupo de pesquisa do projeto de reestruturação do Programa de Desenvolvimento da Faixa de Fronteira - PDFF que abrange o Cone Sul-Mato-Grossense - Fronteira Brasil/Paraguai realizou um estudo de caso, em 2004. A pesquisa alcança as seguintes cidades: Sidrolândia, Dourados, Maracaju, Naviraí, Rio Brilhante, Mundo Novo, Guaíra, Salto del Guairá (Paraguai), Japorã, Coronel Sapucaia, Capitán Bado (Paraguai), Amambaí, Ponta Porã, Pedro Juan Caballero (Paraguai), Bela Vista e Bella Vista (Paraguai).

Segundo a pesquisa, a agricultura e o agronegócio vêm crescendo de forma específica. Desde 1930, com a criação de colônias agrícolas em Dourados, estabelecidas pelo Governo Federal como projeto de frente pioneira, instalaram-se vários assentamentos de nordestinos e sulistas que produzem lavouras para subsistência, marcando o primeiro sistema de produção. Ocorreu, ainda, a expansão da produção de soja, com grande rede de armazenamento e estocagem, e mais tarde estabeleceu-se o cultivo de mandioca para a produção de amido, este em constante crescimento aumentando o sistema produtivo agroindustrial conforme os avanços tecnológicos. As várias aplicações do amido, desde a produção de alimentos até conservantes químicos e plásticos biodegradáveis, têm se expandido até a fronteira com o Paraguai para fins industriais. Com isso fábricas de amido foram implantadas para além da fronteira brasileira, ocupando antigas produções de soja, para o cultivo de mandioca, assim, causando certos prejuízos ao país vizinho, uma vez que, o preço da mandioca ao consumidor, sofreu elevações significativas no mercado local. (PDFF, 2005) 
As "cidades-gêmeas" no Cone Sul-Mato-Grossense que fazem fronteira entre Brasil e Paraguai, segundo o projeto são: Bela Vista/Bella Vista; Ponta Porã/Pedro Juan Caballero; Coronel Sapucaia/Capitán Bado. O povoado de Ypejú (Paraguai) que faz fronteira com Paranhos (Brasil) é considerado apenas como conurbação. Outra relação transfronteiriça significativa para os dois países é a Tríplice Fronteira binacional no extremo Sudeste da região, formada por Mundo Novo/MS, Guaíra/PR e a cidade paraguaia de Salto del Guairá. Muitas das "cidades-gêmeas" mantêm seus vínculos por meio do comércio devido ao fluxo de bens e pessoas, proporcionando, no caso do Paraguai, a transição dos "sacoleiros".

\begin{abstract}
A transformação do Paraguai em um grande entreposto ou porto franco no pós-guerra foi uma forma de estimular o comércio transfronteira. Compradores seriam atraídos pelo preço baixo de produtos impossíveis de serem adquirido no país de origem devido aos altos impostos que seus governos cobravam para desestimular as importações e incentivar a produção interna. Foi esta diferença entre normas e políticas nacionais que levou ao aparecimento dos "sacoleiros". Pedro Juan Caballero nunca foi tão importante quanto Ciudad del Este neste comércio. Especializou-se em abrigar bancos que funcionavam como ponte para operações triangulares, mecanismo muito utilizado por empresas e o sistema bancário brasileiro durante os anos de inflação galopante.

A abertura relativa às importações na década de 1990, o controle do processo inflacionário e a reforma do sistema bancário no Brasil reduziram essa função das cidades gêmeas, e foi particularmente prejudicial a Pedro Juan Caballero, pois, ao contrário de sua vizinha no sul (Ciudad del Este), não abrigava as "maquilas" de produtos brasileiros para compensar a redução do turismo de compra e a função bancária. (PDFF, 2005. P. 240).
\end{abstract}

A fronteira Cone Sul-mato grossense é alvo de políticas públicas locais e federais, pois é uma área de interação fronteiriça muito intensa, devido a compras de terras por imigrantes sulistas há trinta anos, com a criação de gado, plantação de soja e exploração de madeira. Hoje essas áreas se tornaram unidades produtoras mecanizadas com pouquíssima mão-de-obra local. A compra e exploração de grandes extensões de terras paraguaias por brasileiros é resultado da facilidade de fluxo entre os países vizinhos e pelo baixo preço dos produtos e bens, como no caso do Paraguai onde a terra é mais barata. (PDFF, 2005)

A ocupação de terras por estrangeiros no Paraguai motivou grandes movimentos de migração. Migração é um movimento em interação com as dinâmicas dos espaços e sociedades regionais e locais, podendo modificar a estrutura do território. Segundo pesquisas realizadas por Souchaud, Carmo e Fusco (2007), a ocupação do espaço na região da fronteira entre o Brasil, a Bolívia e o Paraguai se distribui por três periferias nacionais: o departamento de Santa Cruz, correspondente a uma parte do "Oriente" da Bolívia, o estado do Mato Grosso do Sul, unidade federativa brasileira e o Chaco Paraguaio, composto por três departamentos: Alto Paraguai, Boquerón e Presidente Hayes. O Chaco Paraguaio possui 60,7\% do território nacional e apenas 2,6\% da população, considerado um deserto demográfico, e na faixa de fronteira a baixa densidade é ainda mais relevante. No departamento Alto Paraguai a cidade fronteiriça é La Victoria com uma população ínfima. A concentração demográfica se dá no Oeste do país. Já no departamento de Santa Cruz possui 33,7\% do território nacional e $24 \%$ da população boliviana, ou seja, comparado ao anterior é um peso demográfico em âmbito nacional. Na divisa de Santa Cruz com Mato Grosso há duas cidades de fronteira, Puerto Súarez e Puerto Quijarro, porém, neste departamento, os habitantes se concentram em peso mais ao ocidente, sendo a fronteira pouco ocupada e integrada. (SOUCHAUD; CARMO; FUSCO. 2007. P.40-42).

Na linha de fronteira, o Paraguai possui uma população quase nula, um contraste quando comparada ao lado brasileiro, cujo espaço urbano concentra-se em maior trecho, Corumbá-Ladário. Há uma baixa ocupação rural e urbana no interior da zona de fronteira, enquanto, nas áreas mais próximas dos limites e nas regiões 
centrais ocorre uma concentração significativa dessas atividades.

O processo de povoamento surgiu em áreas próximas ao rio Paraguai, onde se concentram as atividades econômicas, formando um eixo de penetração e comunicação, desde a época colonial. Foram fundadas localidades-guarnições ao largo do rio, onde se desenvolviam atividades extrativistas e agropecuárias, tornando a área num eixo de redistribuição, como extração mineira, produção de carne e couro bovino (no Mato Grosso) e a exploração da erva mate, destinando os seus produtos aos grandes centros litorâneos da faixa atlântica. À medida que o comércio fluvial se desenvolveu, os centros urbanos ganharam importância diversificando e intensificando a produção. (SOUCHAUD; CARMO; FUSCO. 2007).

Aos poucos, os recursos extrativistas foram se extinguindo parcialmente e, com a concorrência internacional, a dinâmica regional se estagnou. Já no século XX, a partir da década de 1920, a colonização internacional estabeleceu-se na região, com os menonitas (norte americanos com estilo próprio de vida tradicional), estes desenvolveram cultivos e, em especial, a pecuária bovina para a produção de leite, uma atividade dominante ainda hoje. Mas, quanto à ocupação das áreas, mesmo com os programas nacionais de reforma agrária com incentivos à colonização da parte oriental do departamento de Santa Cruz, ainda assim, não se alcançou a zona de fronteira, concentrando-se no extremo oeste. Já no lado brasileiro, os municípios da fronteira, Corumbá, Ladário e Porto Murtinho e seus espaços rurais, são dominados por fazendas de criação extensiva de gado bovino. (SOUCHAUD; CARMO; FUSCO. 2007).

Mesmo diante de uma intensa migração fronteiriça, não há traços de união entre os diferentes espaços, pois, os percursos migratórios não almejam a fronteira strictus sensu, mas sim, para além da zona de fronteira, confirmando o seu "vazio demográfico". Muitos lugares servem bem como pontos de fluidez, facilitando e ampliando o intercâmbio, até mesmo um caminho para grandes cidades como São Paulo, Rio de Janeiro, cidades do Paraná e cidades andinas, conforme a dinâmica continental, acompanhando os eixos rodoviários e fluviais.

Esse programa de desenvolvimento da faixa de fronteira idealizado e projetado pelo governo brasileiro incita um novo olhar para as suas fronteiras a Oeste. Vários anos foram dedicados às fronteiras do atlântico, devido ao próprio contexto histórico do Brasil, um Estado preocupado com sua repercussão internacional de cunho capitalista, investindo toda a atenção do país para o seu desenvolvimento econômico diante do mercado mundial. Mas hoje, reconhece-se a estrutura e a importância da zona de fronteira terrestre, encarando complexos desafios locais e regionais. Um olhar para além da linha que divide, juridicamente, os limites do território.

Como foi visto, ao se tratar das interações e dos conflitos fronteiriços que engendram as dinâmicas locais e regionais, percebe-se que há uma heterogeneidade nos aspectos sociais e culturais nos diferentes espaços levantados neste trabalho, embora a globalização instigue a sociedade a viver um "mundo sem fronteiras". Contudo, as diversidades existentes nos diferentes espaços ainda constam como uma problemática para as políticas dos Estados. Estes tentam adaptar leis e normas que atendam a esses lugares, mas ainda, não dominam fenômenos como o contrabando de mercadorias, armas e drogas. Nesse sentido, cada região específica contida na faixa fronteiriça deve ser levada em conta sem suas particularidades.

\section{CONSIDERAÇÕES FINAIS}

Conforme elucidado, a conceituação sobre fronteiras e limites, distinguindo seus significados e a importância particular de cada uma, foi de extrema importância para a compreensão da formação e o 
estabelecimento dos limites entre os Estados sul americanos. O histórico da formação territorial, definindo os limites entre o Brasil e seus vizinhos (a Bolívia e o Paraguai, mais particularmente) permite-nos entender os relacionamentos entre esses países e a origem das comunidades fronteiriças, bem como as problemáticas que as circundam. Esses dois países limítrofes com o Brasil foram escolhidos por pertenceram a uma região onde a faixa de fronteira está emaranhada de conflitos e integrações bastante atípicas. Os casos do Paraguai - que concentra grande número de "cidades-gêmeas" - e, da Bolívia - em que a problemática do contrabando e do tráfico de drogas - gera “dores de cabeça” aos Estados responsáveis pelas regiões fronteiriças, ainda são notícias em jornais, revistas e telejornais.

Fazem-se necessários estudos de caso, para que possa ser discutida a questão da fronteira como um lugar de unidade ou disparidade. A temática referente à globalização e à ideia de homogeneização não pode ser concluída apenas pela análise do ponto de vista do sistema produtivo, mesmo havendo comunicação entre sociedades distintas, através dos recursos tecnológicos. Os limites não deixaram de existir, porém, as zonas de fronteira, encontram-se hoje, na América do Sul, em intenso processo de aproximação, em que, evidentemente, afloram muitos conflitos revelando as modificações advindas de um novo comportamento de uma sociedade, cada vez mais, informatizada e globalizada.

\section{REFERENCIAS BIBLIOGRÁFICAS}

ALBURQUERUE, J.L.C. Fronteiras e identidades em movimento fluxos migratórios e disputa de poder na fronteira Paraguai-Brasil. Cadernos Ceru, série 2, v.19, n.1, jun.2008. Disponível em: http://www.revistasusp.sibi.usp.br/pdf/ceru/v19n1/04.pdf acesso em: 07/10/2010.

ANDRADE, M. C. Geopolítica do Brasil. Série Princípios. São Paulo. Editora: Ática. 2a edição. 1993.

BRASIL. Ministério da Integração Nacional. Proposta de Reestruturação do Programa de Desenvolvimento da Faixa de Fronteira. Bases de uma política integrada de desenvolvimento regional para a Faixa de Fronteira. Brasília: MI/IICA, 2005.

BURNS, E.B. As relações internacionais do Brasil durante a Primeira República. IN: BORIS, Fausto. História geral da civilização brasileira. Tomo III. $2^{\circ}$ vol. Sociedade e Instituições (1889-1930). $3^{\text {a }}$. Ed. São Paulo: Difel, 1985.

DAI - Divisão de Atos Institucionais. Tratado de Limites, complementar do de 1872. Disponível em: http://www2.mre.gov.br/dai/b_parg_18_3218.htm Acesso em 06/2011.

FREIRE, E. M. Bolívia: Crise de coesão territorial no coração da América do Sul. São Paulo. 2008. $116 f$. Dissertação (Mestrado em Geografia). USP. Faculdade de Filosofia, Letras e Ciências Humanas. Universidade de São Paulo.

GARCIA. D. S. C. A ocupação de terras por estrangeiros de terras na fronteira oeste do Brasil nos primórdios da República: Ocupar para desintegrar. Disponível em: http://www.abphe.org.br/congresso2003/Textos/Abphe_2003 57.pdf. Acesso em: 15/09/2010.

GEIGER, Pedro Pinchas. Identidade Continental Americana In: Questões Territoriais na América Latina. CLACSO. USP, São Paulo, 2006. P. 153-154.

HISSA, C.E.V. A mobilidade das fronteiras: inserções da geografia na crise da modernidade. Belo Horizonte: Editora UFMG, 2002. 
HOLANDA, S. B. O extremo Oeste. São Paulo. Brasiliense: Secretaria de Estado da Cultura. 1986.

MACHADO, L. O. Ciência, Tecnologia e Desenvolvimento regional na Faixa de Fronteira do Brasil. Disponível em: http://www.cgee.org.br/ Acesso em 06/09/2010.

MACHADO, L. O. Limites, Fronteiras e Redes. In: T.M.Strohaecker, A.Damiani, N.O.Schaffer, N.Bauth, V.S.Dutra (org.). Fronteiras e Espaço Global, AGB-Porto Alegre, Porto Alegre, 1998, p.41-49. Disponível em: http://acd.ufrj.br/fronteiras/pesquisa/fronteira/p02pub.htm. Acesso em 02/09/2010.

MACHADO, L.O. Estado, Territorialidade, redes. Cidades Gêmeas na zona de fronteira sul-americana. In: SILVEIRA, M.L. (Org.). Continente em Chamas: globalização e território na América Latina. Rio de Janeiro: Ed. Civilização Brasileira, 2005. P.245 - 281.

MAGNOLI, Demétrio. O corpo da pátria: imaginação geográfica e política externa no Brasil (1808-1912). São Paulo. Editora da Universidade Estadual Paulista: Moderna. 1997. P. 45-77.

Mapa dos departamentos do Paraguai. Disponível em: http://www.portalsaofrancisco.com.br/alfa/paraguai/mapado-paraguai.php Acesso em 06/2011.

MARTIN, André. Fronteiras e nações. São Paulo: Contexto, 1997.

MENDONÇA, C. Impactos de Processos de integração em Zonas de Fronteira: $O$ crescimento dos fluxos comerciais e o desenvolvimento em cidades-gêmeas do Mercosul. Brasília 2009. Disponível em: http://vsites.unb.br/ics/ceppac/conteudo/serie/026_mendonca_2009.pdf Acesso em 06/09/2010.

NOGUEIRA, V.M.R.; DAL PRÁ, K.R. Mercosul: expressões das desigualdades em saúde na linha da fronteira. Revista Ser Social, Brasília, n. 18, p. 159-188, jan./jun. 2006. Disponível em: http://seer.bce.unb.br/index.php/SER_Social/article/viewArticle/186. Acesso em: janeiro/2011.

OLIVEIRA, Márcio Gimene de. A fronteira Brasil-Paraguai principais fatores de tensão do período colonial até a atualidade. Brasília. 2008. 110f. Dissertação (Mestrado em Geografia). UNB. Universidade de Brasília.

RIBEIRO, L.P. Zonas de Fronteira internacionais na atualidade: uma discussão. Rio de Janeiro: UFRJ, 2002, 29p. Disponível em: http://acd.ufrj.br/fronteiras/pesquisa/fronteira/p02avulsos.htm. Acesso em 02/09/2010.

STEIMAN, R. MACHADO, L.O. Limites e Fronteiras Internacionais: uma discussão histórico-geográfica. Rio de Janeiro: UFRJ, 2002. Disponível em: http://acd.ufrj.br/fronteiras/pesquisa/fronteira/p02avulsos.htm. Acesso em 02/09/2010.

STEIMAN. R. Brasil e América do Sul: Questões institucionais de fronteira. Grupo Retis. Disponível em: http://acd.ufrj.br/fronteiras/pesquisa/fronteira/p02avulsos.htm. Acesso em: 13/11/2010.

Tratado de Limites Brasil/Paraguai 09 de Janeiro de 1872. Disponível em: http://www.info.lncc.br/ptt1872.html Acesso em: 06/2011. 